\title{
GRAMÁTICA Y ESTILÍSTICA DE LOS TROPOS
}

\author{
MARIA DEL CARMEN DÍAZ BAUTISTA \\ (Universidad Complutense de Madrid)
}

\section{TROPOS}

Bajo el término tropos se agrupan una serie de estrategias discursivas estudiadas tanto por la retórica, como por la poética. Con los tropos la Retórica busca el convencimiento de lo argumentado, el movere, mientras que la Poética los utiliza como instrumento y medio del delectare; su finalidad es por tanto estética. La inclusión de los tropos en la poética implica una retorización de la misma, así el artificio léxico puede ser objeto de acierto poético.

La definición más simple que podemos dar de los tropos es la de sustitución de una(s) palabra(s) por otra(s). Es decir allí donde cabría esperar un término (A) aparece un término (B), pero la simplicidad de este postulado tradicional no debe ocultarnos las dificultades que tal presuposición encierra, a saber: ¿Cómo es posible la creación de los tropos y su correcta interpretación?, ¿Afecta el tropo sólo una palabra?, ¿Debe tenerse en cuenta el contexto?, etc.

Como veremos más adelante, los problemas que la tropología ha planteado han obtenido muy diversas respuestas, desde las más variadas perspectivas: semánticas, sintácticas, pragmáticas, filosóficas, etc., pero a nuestro juicio casi siempre se escamotea lo que es su raíz, su principio fundamental, el porqué el hombre es capaz de expresar una idea o una realidad con un término impropio y a su vez orientarse en un mensaje y descodificar correctamente un enunciado figurado, sobre todo si se tiene en cuenta que esta propiedad del lenguaje figurado no es exclusiva de la lengua literaria pues los tropos se utilizan constantemente en ell llamado lenguaje referencial.

Jakob Bronowski en una obra titulada The origins of knowledge and imagination ${ }^{1}$

${ }^{1}$ Vid. J. Bronowski: The origins of knowledge and imagination, New Haven and London, Yale University Press, 1978, pp: 21-63. 
relaciona la capacidad humana del lenguaje con las dimensiones y evolución del cerebro humano por una parte y por otra con los rasgos propios de la cultura humana que nos llevan a una representación mental del mundo distinta a la visión animal, es interesante deternos por un momento en la revisión de las hipótesis de Bronowski, ya que pueden servirnos de ayuda para demostrar que los tropos tienen justificación en la esencia misma del lenguaje humano. En un principio este autor compara el lenguaje animal con el lenguaje humano y observa las siguientes diferencias: 1) El ser humano es capaz de retardar las respuestas frente al animal que responde inmediatamente al estímulo de un mensaje. 2) El hombre puede distinguir la información de un mensaje, analizarla, mientras que el lenguaje animal y el lenguaje de las máquinas son recibidos comoórdenes. 3) El lenguaje humano es internacional. 4) El lenguaje humano es generativo.

Todas estas características del lenguaje humano han permitido que nuestra visión del mundo sea distinta a la de los animales; el lenguaje humano no se presenta como un continuo, sino que es analizable en unidades, y nos permite un grado de abstracción que hace posible la expresión simbólica. Así, podemos enunciar un principio, por ejemplo la ley de gravedad, y realizar una notación simbólica, una fórmula. Este proceso hace posible el desarrollo científico (pensemos en las fórmulas químicas). Incluso por esta propiedad podemos concebir realidades mediante el lenguaje que no son inmediatamente perceptibles por los sentidos, como la teoría de la relatividad; el lenguaje nos permite así imaginar la realidad. No creo interpretar incorrectamente el pensamiento de Bronowski si digo que concibe la relación lenguaje-mundo como una interrelación, la capacidad de análisis de la realidad nos permite un lenguaje abstractivo y ese lenguaje nos permite imaginar el mundo. Para este autor el mismo proceso que permite la construcción científica es el que permite la metáfora y todos los tropos en general.

Más adelante analizaremos cómo es posible y qué mecanismos intervienen en la formación y descodificación de los tropos, pero lo que queremos hacer constar de momento es el hecho de que su formulación está en la raíz misma del lenguaje humano capaz de formular mensajes más o menos alejados de la referencialidad, pero por sí mismo capaz de hacer surgir un conocimiento imaginable. Del mismo modo una frase es equivalente a una fórmula, un término $(A)$ es equivalente a (B) y el mismo proceso imaginativo que nos sirve para interpretar una fórmula nos orienta en la construcción de una nueva referencialidad a partir de un tropo ${ }^{2}$.

Conviene ahora delimitar cuáles son las figuras que se agrupan bajo el rótulo de tropos, la tarea no es sencilla ya que la expresión del concepto ha variado de forma

${ }^{2}$ Cf. J. Molino, F. Soublin Y J. Tamine: «Présentation: Problèmes de la métaphore», Langages, 54 , 1979, pp: 5-39. En este artículo los autores hacen varias manifestaciones en el mismo sentido expresado por nosotros, así afirman: «C'est qu'à côté de l'entendement qui analyse, sépare et distingue, existe une faculté qui synthétise, rassemble et rapproche selon les lois de l'analogie. Qu'on l'appelle Raison —opposée a l'Entendement- ou Imagination —que Coleridge oppose à Fancy-, cette faculté est à l'oeuvre aussi bien dans la perception (imagination primaire de Coleridge) que dans le langage qui, à l'origine, est langage métaphorique. La métaphore unit ce qui est à la fois semblable et dissemblable: elle est la forme de la connaissance créatrice qui fait la synthèse du divers et unit semblable et contraires dans une totalité organique et vivante» (pág. 16). 
considerable a lo largo de la historia retórica ${ }^{3}$. En la actualidad suelen incluirse sólo tres figuras: metáfora metonimia y sinécdoque (las Ilamadas figuras de pensamiento), pero la tendencia reduccionista no acaba ahí ya que la hipótesis jakobsoniana ${ }^{4}$ que establece una división bipolar de las figuras: figuras por sustitución, (metáfora), y figuras por contigüidad, (metonimia y sinécdoque).

\section{METÁFORA}

\subsection{Metáfora y comunicación.}

Decíamos en el epígrafe anterior que los tropos son estudiados por la retórica como instrumentos destinados al movere y por la poética como recurso artístico; $\sin$ embargo, este hecho no debe llevarnos a la conclusión de que existen unos límites estrechos en la aparición de los tropos. Estos artificios lingüísticos trascienden el ámbito del discurso retórico y del literario para instalarse en el lenguaje coloquial e incluso en el científico ${ }^{5}$ : podemos quedar citados con unos amigos para tomar una copa (metonimia); un ganadero puede comprar 30 cabezas (sinécdoque) más para su rebaño, o bien podemos intentar reparar la pata (metáfora) de la mesa rota. En todas las expresiones antes citadas encontramos figuras lexicalizadas, —el mayor o menor grado de lexicalización hace que para los hablantes pasen casi desapercibidas-, pero estas figuras, y sobre todo la metáfora, son capaces de crear una serie de sistemas conceotuales que a modo de principios o axiomas configuran nuestra visión del mundo e incluso inspiran el desarrollo científico instalándose en la base de nuestras creencias más profundas.

\subsubsection{La metáfora en el lenguaje referencial}

Con frecuencia se ha considerado que el lenguaje literario consistía en un uso desviado del lenguaje estándar estableciéndose una oposición entre ambos, y uno de los rasgos que marcan esa oposición es la utilización de convenciones o marcas de

\footnotetext{
${ }^{3} \mathrm{~F}$. Soublin, titula un artículon aparecido en la revista Langages: $« 13 \Rightarrow>30 \Rightarrow>3 »$ en el que se analizan los distintos rótulos que el desplazamiento y sustitución de términos en los tropos ha sufrido a lo largo de la historia. Vid. F. Soublin: «13 $\Rightarrow 30 \Rightarrow 3 »$, Langages, 54, 1979, pp: 41-63.

${ }^{4}$ Una exposición breve de las ideas de Jakobson puede encontrarse en R. Jakobson y M. Halle: Fundamentos del lenguaje, Madrid, ayuso, 1973, y en R. Jakobson: Lingüística, poética, tiempo (conversaciones con Krystina Pomorska), Barcelona, Crítica, 1981.

${ }^{5}$ Son muchos y muy variados los campos en los que la metáfora ejerce su función de creación, en el artículo antes citado de Molino y otros autores podemos leer: «Nous voudrions seulement mentionner trois domaines où les divers fonctions de la métaphore mériteraient d'être décrites: le domaine scientifique, le domaine du rite et de la culture, auxquels sont consacrés deux articles de ce numéro, enfin le domaine de l'argumentation, auquel nous allons consacrer quelques lignes» (op. Cit., pág. 36). Pero también la metáfora puede ser con su facultad creadora la base de otra creación, la literaria, tal y como lo hizo notar R. Barthes a propósito de la novela de Bataille Histoire de l'Oeil, vid. R. Barthes: «La metáfora del ojo», Ensayos críticos, Barcelona, Seix Barral, 1977.
} 
expresividad (entre ellas los tropos). Esto resulta ser cierto sólo parcialmente pues existe una gradación en el uso de las convenciones expresivas; por ejemplo, la métrica es un recurso que marca la voluntad del autor como creador de un texto literario, pero el uso de metáforas, si bien son portadoras de expresividad, no garantizan con su aparición que estemos ante la presencia de un texto no ya poético, sino literario. Creemos que lo que distingue en último término el lenguaje referencial del literario es la voluntad del emisor, en el primero, de dar una información o una instrucción frente a la voluntad, en el segundo, de construir (con acierto o no) un discurso artístico.

Por tanto, relegar el uso de las metáforas al ámbito estricto de la lengua literaria o poética, considerándolas un desvío del lenguaje e incluso, es opinión de ciertos sectores de lingüistas, sin interés para la ciencia del lenguaje, nos parece un error ${ }^{6}$.

La metáfora está presente en el lenguaje referencial y comunicativo y constituye a la vez un mecanismo de creación del lenguaje. En este mismo sentido se manifiesta Coseriu ${ }^{7}$ cuando afirma:

...el conocimiento lingüístico es muchas veces un conocimiento metafórico, un conocimiento mediante imágenes, las cuales, además, se orientan tan a menudo en el mismo sentido que nos hacen pensar seriamente en cierta unidad universal de la fantasía humana por encima de las diferencias idiomáticas, étnicas o culturales.

Son muchos los ejemplos que cita Coseriu como testimonio de esta actividad creadora, fruto de la imaginación o la fantasía cuando esta se proyecta sobre el léxico, cuchara < caracol, barrena $<$ verraco, etc.

La metáfora no es sólo la fuente de creación léxica, sino que, como decíamos al principio, crea toda una red de significados metafóricos a los que Weinrich llamaba campo de imágenes y que define en los siguientes términos: «El campo de imágenes, por el contrario, pertenece a la objetiva y virtual configuración social del lenguaje y se comporta respecto de la alegoría como la configuración de la lengua de Saussure respecto a una secuencia de actos de habla» ${ }^{8}$.

${ }^{6}$ Podemos leer en R. J. Matthews: «Concerning a Linguistic Theory of Metaphor», Foundations of Language, 7, 1971, pp: 413: «Recent discussions, apparently as a result of the continued interest in 'deviant sentences' and 'meaningless utterances', have again called our attention to the question of metaphor: a semantic theory, expalins for example the late Uriel Weinreich (1966, pp: 471), is of «marginal interest if it is incapable of dealing with poetic uses of language, and more generally with interpretable deviance». También T. Reinhart inicia un artículo con la siguiente afirmación: «A recent debate in linguistic discussions of metaphor concerne the questions of whether there is such a thing as semantic deviance and whether there is such a thing as semantic deviance and whether metaphor can be treated as instance of such deviance. The notion of semantic deviance stems form carly generative works such as Chomsky (1964; 1965), Katz (1964), and Ziff (1964).» Cf. T. Reinhart: «On understanding poetic metaphor», Poetics, 5, North-Holland, 1976, pp: 384-402.

${ }^{7}$ Vid. E. Coseriu: «La cración metafórica», El hombre y su lenguaje, Madrid, Gredos, 1977, pp: 80. Y más adelante, sobre la metáfora lexicalizada afirma: «Nos encontramos frente a intentos de clasificar la realidad, ya no mediante categorías de la razón, sino mediante imágenes, y frente a analogías establecidas, no desde un punto de vista estrictamente formal, entre vocablos, sino poéticamente, entre «visiones», que deben haber surgido, en cierto momento particular, de la fantasía creadora de alguien». (pág. 81).

${ }^{8} \mathrm{H}$. Weinrich: Lenguaje en textos, Madrid, Gredos, 1981, pp: 359. 
Estos campos de imágenes actúan tanto diacrónica como sincrónicamente. Weinrich cita algunos: ver la palabra como una moneda, la memoria como un almacén o la memoria como una tablilla de cera.

Todavía podemos aportar en favor de nuestra tesis un nuevo testimonio, el de Lakoff y Johnson ${ }^{9}$. Estos autores, en su obra Les métaphores dans la vie quotidienne observan como en nuestras actividades y experiencias proyectamos una actividad metafórica conformadora de gran número de sistemas conceptuales; así las redes metafóricas, que denominan orientadoras, por las que podemos contemplar realidades abstractas como objetos dimensionales: concebimos la felicidad o lo mejor como lugares altos, de este modo 'estar eufórico' es 'estar en el séptimo cielo' y en contrapartida uno puede 'caer' en la depresión. Otra red metafórica es la ontológica; merced a ella podemos concebir entidades abstractas como sustancias, y de este modo obtenemos expresiones metafóricas del tipo: 'la inflacción sacudió al país', 'se necesita mucha paciencia para realizar esta tarea'. Un tercer campo metafórico es el estructural, por el que se establece la similaridad entre conceptos y objetos; por ejemplo, establecer una similitud entre las ideas y los alimentos, o comparar dos ideas abstractas: una discusión es como una guerra.

Estos campos metafóricos crean todo un sistema conceptual metafórico ampliable mediante la interrelación y combinación de los distintos mecanismos creadores de campos metafóricos.

\subsubsection{La metáfora en el lenguaje científico}

Decíamos en las páginas anteriores que las metáforas inspiran nuestras creencias más profundas, podemos encontrar metáforas en casi todos los libros sagrados ${ }^{10}$, pues el juego de las similitudes permite un conocimiento más inmediato y vivencial de realidades abstractas. Pero también esta figura se encuentra presente en los trabajos científicos, no sólo en el empleo discursivo del lenguaje científico, sino incluso como principio inspirador, como axioma a partir del cual se desarrolla una determinada orientación investigadora; en este mismo sentido se expresa C. Normand en su obra Métaphore et concept ${ }^{11}$, aunque su tesis va más allá de la simple demostración de metáforas creadoras y organizadoras de principios científicos, pues lo que intenta demostrar es el hecho de que distintas metáforas funcionan como suplemento (teoría deconstructivista) en la creación científica, tarea que realiza con rigor, pero esta finalidad no es la que aquí y ahora nos interesa; lo que sí queremos resaltar es el hecho del origen metafórico de distintos principios científicos tales como la idea de la «lengua como un organismo»; esta metáfora llevó a los lingüistas del pasado siglo a orientar sus investigaciones lingüísticas por el camino del comparativismo. Otros términos igualmente metafóricos como «parentesco entre lenguas», «descomposición linguiística», «raíces y genealogías», «desarrollo y muerte de las lenguas», que

\footnotetext{
${ }^{9}$ G. Lakoff y M. Johnson: Les métaphores dans la vie quotidienne, Les Editions de Minuit, 1985.

${ }^{10}$ Vid. N. Frye: El gran código, Barcelona, Gedisa, 1988.

"Cf. C. Normand: Métaphore et concept, Bruxelles, Editions Complexe, 1976.
} 
pasaron a ser de dominio común en la terminología lingüística hasta que una nueva metáfora orienta por distintos derroteros los estudios lingüísticos, cuando la lengua no se conciba ya como un organismo, algo vivo, sino como un sistema de signos, una estructura que debe ser analizada, estudiada en función de la jerarquía de sus constituyentes.

Estos ejemplos que acabamos de aducir nos sirven para confirmar lo anteriormente dicho; el fenómeno de la metáfora no es exclusivo de la lengua literaria y tiene su origen en la especial forma del ser humano de configurar su pensamiento.

\subsubsection{La metáfora y los estudios literarios}

Aristóteles en la Poética dice de la metáfora:

La metáfora es el traslado de un nombre de una cosa al de otra, o del género a especie o de la especie al género o de la especie a otra especie, o según la analogía ${ }^{12}$.

La tradición retórica y poética ha venido considerando como metáfora sólo el traslado como analogía y ha considerado tropos las restantes traslaciones, esto ya lo observa P. Ricoeur cuando afirma que la metáfora de Aristóteles es el tropo de Fontanier, y la metáfora de Fontanier es la cuarta clase de metáfora de Aristóteles ${ }^{13}$.

Continúa Aristóteles desarrollando la idea de analogía y dice:

Entiendo por analogía el hecho de que el segundo término es al primero como el cuarto al tercero; así pues, se utilizará el cuarto en vez del segundo o el segundo en vez del cuarto, y algunas veces se añade el têrmino al que se refiere la palabra reemplazada ${ }^{14}$.

El concepto de analogía ${ }^{15}$ implica por tanto una idea de proporcionalidad ${ }^{16}, \mathrm{y}$ más adelante añade que metaforizar bien es ver bien lo semejante. Ambos conceptos, analogía y semejanza han estado presentes a lo largo de toda la tradición tropológica

\footnotetext{
${ }^{12}$ Aristóteles y Horacio: Artes poéticas (Edición biblingüe de Aníbal González), Madrid, Taurus, 1987, pp: 80 .

${ }_{13}^{13}$ P. Ricoeur: La metáfora viva, Madrid, Europa, 1989, pp: 86.

${ }^{14}$ Op. cit., pág. 81.

${ }^{15}$ Sobre los tipos de analogía afirman J. Molino y otros autores lo siguiente: «Suivant les distinctions proposées en logique et en epistémologie par Keynes et M. Hesse, nous définissons trois types d'analogie (ou, si l'on veut, de ressemblance) entre les deux termes $N$ et N' (Hesse, 1970): 1) l'analogie positive, qui comprend les sèmes communs à $\mathrm{N}$ et $\mathrm{N}$ ' dans l'état de connaissances donné de celui qui interpréte la métaphore; 2) l'analogie négative, qui comprende les sèmes présents dans l'un des termes et incompatibles avec les sèmes de l'autre terme; enfin et surtout 3 ) l'analogie neutre, c'est-à-dire les traits pur lesquels nous ne savons pas s'ils sont communs aux deux termes». (op. cit., pp: 30).

${ }^{16}$ Asimismo en Molino, VV.AA. se puede leer en relación con la proporcionalidad: «Le psychologue Spearman deffinissait l'intelligence par la même configuration: si l'on donne une relation (A est à B) et un terme (c), l'acte d'intelligence consiste 'a évoquer immédiatement le terme corrélatif (d)» (Molino y VV.AA., op. cit., pp: 31 ).
} 
como unas constantes inalterables. La semejanza es la base de sustitución metafórica, los cambios entre género y especie así como sus posibles combinaciones dan lugar al juego metonímico y sinecdótico. Sin embargo parece haberse mantenido en el olvido la idea que subyace en la definición aristotélica, una visión del mundo estructurada y organizada, una especie de diagrama (géneros y especies) a modo de escala que permite la sustitución de términos en sentido ascendente, descendente u horizontal.

La idea de metáfora como sustitución de términos por una relación de semejanza ha tenido como consecuencia el hecho de que durante mucho tiempo se le considerara tropo de una sola palabra ${ }^{17}$. Sin embargo, desde el principio se observó en la sustitución el efecto expresivo y la potencia creadora de un nuevo significado; mediante la metáfora se construye un concepto imaginario nuevo y más rico en información como demostrarán los estudios semánticos de la metáfora ${ }^{18}$.

Si como decíamos en páginas anteriores la poética se retorizó al incorporar los artificios léxicos de la retórica y convertirlos en instrumentos hábiles para el efecto estético, con el ocaso de la retórica ésta se vio poetizada, pues, reducida a la lexis, los estudios retóricos se contemplan como listas de tropos o figuras al servicio de la poética. Como acertadamente señalan J. Molino, F. Soublin y J. Tamine en su artículo «Présentation: Problémes de la Métaphore» ${ }^{19}$, la retórica tras una etapa de languidez vuelve a estar de moda; este reciente interés por la ciencia retórica y en especial por los estudios sobre la metáfora vienen de la mano, según estos autores, del interés que en la actualidad despierta el estudio del significado relegado e incluso despreciado durante el período estructuralista.

Lo cierto es que la retórica y sobre todo la metáfora son objeto de interesantes estudios en la actualidad, con la esperanza, al aplicar a los mismos técnicas linguísticas más avanzadas, de desentrañar de una vez por todas el halo misterioso que la producción metafórica encerraba. La sintaxis, la semántica, la pragmática y la semiología han contribuido notablemente en esta tarea.

\subsubsection{La metáfora analizada por la semántica.}

La semántica estructural al analizar y descomponer los significados de las palabras en unidades mínimas significativas, los semas, justifica lacreación metafórica y su interpretación por la coincidencia entre uno o más semas comunes existentes

${ }^{17} \mathrm{P}$. Ricoeur establece una posición entre los estudios que clasifican la metáfora como tropo de una sola palabra y los que prestan atención al significado discursivo. En cuanto a los primeros, dice Ricoeur, a propósito de la obra de fontanier: «La antigua tropología no constituye en su obra (la de Fontanier) más que una de tantas clases de figuras: las figuras de significación o tropos propiamente tales, es decir, los que constan de una sola palabra». Y más adelante ratifica esta afirmación: «La metáfora queda clasificada entre los tropos de una sola palabra o tropos propiamente dichos». Vid. Ricoeur, op. cit., pp: 83.

${ }^{18}$ Así afirma Eco: «Cuando las figuras retóricas se usan de modo 'creativo', no sirven sólo para 'emblellecer' un contenido ya dado, sino que contribuyen a delinear un contenido diferente» (U. Eco: Tratado de semiótica general, Barcelona, Lumen, 1981, pp: 441.

${ }^{19}$ Op. cit., pp: 5 . 
entre el término metafórico y el término sustituido. Esta forma de argumentación lleva implícita la hipótesis de que la figura nace del juego de oposición entre un término propio y un término figurado o metafórico, manteniéndose en la línea tradicional que contempla la metáfora como figura de una sola palabra, sustitución por analogía.

La presencia de semas comunes entre el término propio y el figurado permite la creación metafórica mientras que para su descodificación es precisa la suspensión de una parte de los semas constitutivos del término metafórico. Esta es por ejemplo la propuesta de Le Guern ${ }^{20}$ :

Mientras que el mecanismo de la metonimia se explicaba por un deslizamiento de la referencia, el de la metáfora se explica a nivel de la comunicación lógica por la supresión, o, más exactamente, por la puesta entre paréntesis de una parte de los semas constitutivos del lexema empleado.

La interpretación que hace Le Guern del análisis sémico de los tropos tiene varias consecuencias; en primer lugar, permite el trazado de una frontera tropológica entre metáfora, de una parte, y metonimia y sinécdoque por otra, ya que éstas surgen por deslizamiento referencial y aquélla por una reorganización sémica en el seno del término sustituido. En segundo lugar Le Guern cree ver una repercusión estilística fruto del propio mecanismo producto de los tropos, a saber, que la metáfora supone una ruptura en la isotopía textual que no es apreciable ni en la metonimia ni en la sinécdoque.

La separación entre metáfora de un lado y metonimia y sinécdoque por otro ya fue apreciada por R. Jakobson, si bien no desde una perspectiva de análisis sémico como en Le Guern, sino por la aplicación de los principios lingüísticos saussurianos paradigma y sintagma al estudio del lenguaje en los afásicos, y los mecanismos de sustitución y combinación en el plano discursivo. Dice Jakobson ${ }^{21}$ :

Toda forma de trastorno afásico consiste en una alteración cualquiera, más o menos grave, de la facultad de selección y sustitución o de la facultad de combinación y contextura. En el primer caso se produce una deteriorización de las operaciones metalingüísticas, mientras que el segundo perjudica la capacidad del sujeto para mantener la jerarquía de las unidades lingüísticas. El primer tipo de afasia suprime la relación de semejanza; el segundo, la de contigüidad.

La tesis de Jakobson ha sido ampliamente seguida por importantes sectores de la crítica, aunque algunas de las conclusiones últimas de sus hipótesis aplicadas a la teoría de los géneros literarios ha encontrado algunas resistencias ${ }^{22}$.

${ }^{20}$ M. Le Guern: La metáfora y la metonimia, Madrid, Cátedra, 1985, pp: 18.

${ }^{21}$ R. Jakobson y M. Hall: Op. cit., pp: 133.

22 Vid. P. Albertelli: «On Metaphor and Metonimy in Jakobson», Cahiers Ferdinand de Saussure, 39, 1985, pp: 111-120. 
Esta división entre figura de sustitución y figuras de combinación no implica en modo alguno una separación tajante, ya que algunos autores intentan justificar el mecanismo productor de las metáforas a partir de los mecanismos productores de la metonimia o de la sinécdoque. Tal es el caso propuesto por A. Henry para quien la metáfora se asienta en una doble metonimia ${ }^{23}$ :

La métaphore est donc fondée sur un double mécanisme métonymique; elle est la synthèse d'une double métonymie en court-circuit; c'est une identification métonymique, ou, si l'on préfère, une superposition métonymique créant dans le discours une synonymie subjective.

El salto metafórico no es para Henry, sino la consecuencia de dospasos metonímicos sucesivos sobre la base de semas comunes. Sin embargo, resulta sorprendente el hecho de que otros autores, los llamados Grupo $\mu$, vean igualmente la metáfora como un doble paso, un doble desplazamiento entre semas, pero no sobre la base de dos metonimias, sino de dos sinécdoques ${ }^{24}$ :

...la métaphore n'est pas à proprement parler une substitution de sens, mais une modification du contenu sémantique d'un terme. Cette modification résulte de la conjonction des deux opérations de base: addition et suppression de sèmes. [...] la métaphore est le produit de deux synécdoques.

Y más adelante especifican los tipos de sinécdoque capaces de producir la metáfora:

Peut-on former une métaphore en combinant librement deux synecdoques quelconques, généralisantes $(\mathrm{Sg})$ ou particularisantes $(\mathrm{Sp})$ ?. Non, car la synecdoque modifiant le niveau des termes, nous devrons obligatoirement combiner une Sg et une Sp si nous voulons que $\mathrm{D}$ et $\mathrm{A}$ soient au même niveau (au même degré de généralité) comme il est de règle pour la métaphore. Il nous reste ainsi les deux possibilités suivantes:

$$
(\mathrm{Sg}+\mathrm{Sp}) \text { et }(\mathrm{Sp}+\mathrm{Sg})^{25}
$$

Aparte de la, quizás sólo aparente, contradicción entre la visión y el tratamiento dado a la metáfora por estos autores las conclusiones a las que llegan nos hacen pensar en una perspectiva integradora en el tratamiento tropológico y nos sugiere la idea de que quizás no se trate tanto de fenómenos de desplazamientos semánticos distintos, como de un mismo y único fenómeno con distintos grados. Recordamos entonces que Aristóteles llama a todos estos tropos metáfora y apuntábamos en páginas anteriores la posibilidad de que bajo la definición del estagirita estuviese implícita una visión organizada del mundo referencial que tiene su reflejo en el

\footnotetext{
${ }^{23}$ A. Henry: Métonymie et Métaphore, Paris, Klinsieck, 1971, pp: 66.

${ }^{24}$ F. Dubois y VV.AA: Rétorique générale, Paris, Larousse, 1970, pp: 106.

${ }^{25}$ Op. cit., pp: 108.
} 
léxico, y el aparente no-sentido o alogicismo de los tropos no es tal, sino que sería una organización particular, un sentido y una lógica distinta la que se proyecta en la producción tropológica.

Analizaremos ahora otras consecuencias semánticas de la utilización metafórica de un término, cuando decimos la metáfora perlas por dientes o rosas por mejillas, un significante, el del término metafórico, amplía su significación barcando en su campo semasiológico el concepto mental de diente o mejilla, de forma momentánea y en un decurso concreto se produce una extensión referencial sobre un procedimiento que no es ajeno a la semántica, el procedimiento de la polisemia, el término metafórico es en realidad un término retóricamente polisémico, aunque en el caso de la metáfora no lexicalizada o metáfora nueva sea una polisemia ocasional. Esta orientación semántica extensional lleva aparejada como contrapartida una modificación del término metafórico en su semántica intensional, una parte del concepto pierde su pertinencia sémica y queda suspendida, aunque permanezca latente en el contexto, por esto es por lo que la metáfora posee un plus expresivo, una sobrecarga semántica como se ha hecho notar en diferentes ocasiones ${ }^{26}$.

Hasta el presente momento hemos observado la semántica de la metáfora desde la perspectiva de la misma como sustitución de términos, es decir, sin tener en cuenta las repercusiones que su utilización tiene en el conjunto textual, discursivo. Pero la metáfora hace su aparición en un texto y posee un contexto lingüístico que no sólo no le es ajeno, sino que sin él el receptor no podría descodificar correctamente la metáfora como muy bien han señalado varios autores ${ }^{27}$; así Max Black cree que la metáfora hay que oponerla al menos con u término que en el texto aparece con valor literal.

«El presidente aguijó la discusión». Al decir de esta frase que es un caso de metáfora implicamos que al menos una palabra (aquí, el vocablo «aguijó») se usa metafóricamente en ella, y que al menos una de las palabras restantes se utiliza con valor literal; vamos a llamar a «aguijó» el foco, y marco al resto de la oración en que aquella aparece ${ }^{28}$.

Sin embargo, pensar que el relieve metafórico proviene sólo del entorno lingüístico en el que se produce la metáfora por la ruptura de la isotopía textual, es

${ }^{26} \mathrm{Eco}$, al aplicar a la metáfora los conceptos de semántica intensional y semántica extensional, considera que permiten distinguir dos tipos de metáforas: «In the meantime, though, it is to studies of this sort that the distinction is owed between what could be called an 'intensional' metaphor and one that is 'extensional'. An example of the first type is The girl is a birch, which, given certain meaning postulates (for example, if young girl then human; if reed then nonhuman), clearly manifests its metaphoricity (otherwise it would be a semantically incorrect expression, or an outright lie). An example of the second type is the emperor entered, an expression which in itself is literal and, semantically speaking, unambiguous, unless it should refer in a particular circumstance to the entrance of an office manager».

U. Eco: Semiotics and philosophy of language, Bloomington, Indiana University Press, 1984, pp: 110.

${ }_{27}$ Una interesante recopilación de los estudios de la metáfora desde la perspectiva discursiva podemos encontrarla en la obra antes citada de Ricoeur, bajo el epígrafe «Metáfora y semántica del discurso»».

${ }^{28}$ M. Black: Modelos y metáforas, Madrid, Tecnos, 1966, pp: 39. 
una visión demasiado angosta del fenómeno semántico, pues lo que prodríamos llamar «contexto cultural» también produce una interacción significativa. La metáfora se da en un texto y el texto es producto de una sociedad que lo engendra y lo interpreta; a su vez toda sociedad posee en circulación una serie de sistemas de tópicos, como los llama Black. Estos tópicos están implicados en los enunciados metafóricos y por ello podemos descodificar en un determinado sentido ciertas metáforas como «el hombre es un lobo para el hombre», merced al tópico de que el lobo es un animal cruel. Si en nuestra cultura contempláramos al lobo como la encarnación de la muerte el sentido de la metáfora sería muy distinto del que normalmente damos a esta frase.

\subsubsection{Metáfora y gramática.}

Las metáforas se construyen sobre la base de las categorías gramaticales, el nombre, el adjetivo, el verbo y el adverbio que son las categorías portadoras de un sentido referencial, por tanto la visión gramatical de la metáfora nos habla de metáforas nominales, verbales, adjetivas y adverbiales, según la parte de la oración portadora de valores metafóricos. Mediante las categorías léxicas construimos frases en las que se cumplen determinadas funciones sintácticas: sujeto, predicado o complemento. Un término metafórico pertenecerá por tanto a una categoría léxica y cumplirá una determinada función en el marco oracional. No es extraño, en consecuencia, que la gramática se ocupe de la clasificación de los distintos tipos de metáforas en atención tanto a la clase gramatical portadora de un valor metafórico como en orden a la función que desempeña en el seno clausal dicha categoría ${ }^{29}$.

Las consecuencias de estos análisis quizás no sean tan ricas y espectaculares como lo son las que atienden al análisis semántico, pero no por ello deben de ser desdeñadas y desatendidas si queremos dar cuenta del fenómeno de la metáfora en su totalidad, además ésta es la única posibilidad, -la visión global-, de poder avanzar y desarrollar una hipótesis explicativa del hecho metafórico. Hasta el momento, tanto la metáfora como el resto de los tropos, metonimia y sinécdoque en menor medida, han recibido atención desde diversas perspectivas; todas ellas recuerdan las diferentes caras de un iceberg. Sin embargo, gran parte de las mismas queda ocultae inexplorada y estamos convencidos de que una perspectiva totalizadora, y no parcial, puede poner de manifiesto aspectos importantes de su producción e interpretación.

En líneas generales, las gramáticas de los tropos nos proporcionan la posibilidad de establecer una clasificación tipológica de las figuras; así, J. Tamine en su artículo

\footnotetext{
${ }^{29}$ Son muchos los estudios que desarrollan estas perspectivas gramaticales, entre ellos podemos ver: Tamba-Mecz: Le sens figuré, Paris, Presses Universitaires de France, 1981. E. A. Levenston: «Metaphor, speech act and grammatical form», Poetics, 5, North-Holland, 1976, pp: 373-382. E. Martinell: «Usos verbales metafóricos», Revista de lingü̈́stica, 6, 1976, pp: 369-385. J. Tamine: «L'interprétation des métaphores en 'de' le feu de l'amour», Langue Française, 30, 1976, pp: 34-43. M. Murat: «La métaphore verbal: une mise au point», TraLiLi, XIX-1, 1981, pp: 327-345. J. P. Boons: «Métaphore et baisse de la redondance», Langue Française, 11, 1971, pp: 15-16.
} 
«Métaphore et syntaxe $»^{30}$, sobre la base del esquema metafórico Tp R Tm donde Tp equivale a término propio, $R$ a relación entre los términos y la sintaxis y $T m$ significa término metafórico, introduce un principio de clasificación considerando dos posibilidades: a) metáforas en las que Tp y Tm no pertenecen a una misma parte de la oración. b) Las metáforas en las que Tp y Tm pertenecen a la misma parte de la oración. Del desarrollo de este esquema o propuesta inicial se deducen dos grandes bloques: relacionadas con el primero, esto es con las metáforas en las que Tp y Tm no pertenecen a la misma parte de la oración, la metáfora de verbo u adjetivo, la metáfora de nobre y adjetivo y la metáfora de verbo y nombre (ésta última puede a su vez subdividirse en dos nuevas clases: el término metafórico es el verbo, o bien el término metafórico es el nombre). Del segundo bloque, en el que el Tp y el Tm pertenecen a la misma clase gramatical, caben dos nuevas posibilidades de división: el Tp y el Tm son dos nombres o Tp y Tm son dos infinitivos; si se trata de dos nombres, éstos se pueden relacionar por medio de tres procedimientos sintácticos, mediante un verbo copulativo, por aposición, y con un sintagma preposicional introducido por de. En cuanto a los mecanismos sintácticos capaces de relacionar dos infinitivos obtenemos dos posibilidades, con ser o por aposición.

Esta clasificación de Tamine permite dar cuenta de la distinción entre metáforas in praesentia (las del segundo grupo); y metáforas in absentia (las del primero). Esta distinción de la tropología tradicional no siempre es admitida; así J. A. Martínez ${ }^{31}$ rechaza que la presencia o ausencia del término propio permita establecer una división en el seno de la metáfora, pues en ambos casos se da una reducción por metasemia que es la causante de la aparición de la metáfora. Para Martínez lo lícito es por tanto hablar de dos tipos de imágenes: Imagen in praesentia e imagen in absentia, pero en modo alguno de dos tipos de metáforas ${ }^{32}$. Ciertamente, el análisis que hace este autor de la metáfora no es sintáctico, sino semántico. Tamine, cuando observa esta distinción entre metáfora in praesentia y metáfora in absentia trata de justificarla como una simple coincidencia y evita la noción explícita de sustitución.

Es indudable que la distribución de los constituyentes oracionales tiene importancia en el análisis y la interpretación de la metáfora; así el menor o mayor grado de determinación entre los sintagmas afectados por la metáfora marcarán el grado de extensión semántica y la posibilidad de convertir o no ciertas estructuras predicativas en expresiones nominalizadas.

La importancia de la relación sintáctica en el análisis de la metáfora es un hecho digno de tener en cuenta, incluso (pues estas relaciones son portadoras y generadoras de significaciones) la metáfora se ha contemplado como un fenómeno eminentemente predicativo, implicando en sí misma una funcionalidad. La frontera entre semántica y sintaxis se vuelve ciertamente borrosa cuando se traspasan determinados límites, en este sentido interpretamos la afirmación de Tamine cuando afirma:

Ce mécanisme syntaxique de l'extension de propriétes qui fonde la métaphore est

\footnotetext{
30 J. Tamine: «Métaphore et syntaxe», Langages, 54, 1979, pp: 65-81.

${ }^{31}$ J. A. Martínez: Propiedades del lenguaje poético, Oviedo, Universidad de Oviedo, 1975.

${ }^{32}$ Op. cit., pp: 75 .
} 
donc lié à la notion de classe lexicale et à la relation de ces classes et des cadres syntaxiques.

Evidentemente esto es cierto en alguna medida ya que la división entre sintaxis y semántica responde a una convencionalidad metodológica orientada hacia la reflexión linguística. Tamine pone de relieve el hecho innegable de que las relaciones entre las unidades lingüísticas son productoras de significaciones y hasta ahí estamos de acuerdo, pues todo enunciado se manifiesta como una interrelación de materiales fónicos ${ }^{33}$, estructurados y significativos, sin embargo la conclusión final a la que llega Tamine nos parece desmedida, cuando afirma:

La sémantique n'y intervient que négativement —pour qu'il y ait métaphore, il faut que les termes rapprochés ne soient pas compatibles et c'est la syntaxique qui, moyennant cette condition, supporte la figure: pas de métaphore sans syntaxe, et par conséquent, pas de métaphore ailleurs que dans le langage, sinon précisément par un emploi figuré du $\mathrm{mot}^{34}$.

Si la afirmación anterior excluye la legitimidad de los estudios semánticos de la metáfora debemos manifestar nuestro desacuerdo. Será precisamente, como ya hemos apuntado con anterioridad, aquel modelo de gramática que contemple todos los niveles lingüísticos el que mejores resultados podrá ofrecernos en el estudio de la metáfora y los restantes tropos.

\section{METONIMIA}

Mientras que los estudios sobre la metáfora han alcanzado un gran desarrollo, la metonimia y la sinécdoque no han obtenido una atención paralela. Los trabajos elaborados sobre estas figuras han recibido un tratamiento preferentemente retórico desde una perspectiva taxonómica para determinar las diferentes subclases de este tropo, así como la atención semántica dirigida en unas ocasiones a justificar las diferencias entre metonimia y sinécdoque, o bien en otras como argumento para rechazar tal distinción.

\subsection{Metonimia y lenguaje referencial}

Al igual que la metáfora, la metonimia es una convención expresiva cuyo uso no puede limitarse exclusivamente al lenguaje artístico. La abstracción y la imaginación de los hablantes hacen uso de este tropo en el empleo diario de la lengua; así lo hacen notar Lakoff y Johnson ${ }^{35}$ en el trabajo antes citado. Estos autores no son partidarios de la distinción entre metonimia y sinécdoque ya que consideran a la sinécdoque un

\footnotetext{
${ }^{33}$ Según Morinet la fonética puede ser fuente de creación metafórica, a este respecto vid. Ch. Morinet: «Métaphore, repères et phonetique», Semiotica, 3/4, 1987, pp: 249-258.

${ }^{34}$ Tamine, op. cit., pp: 80.

${ }^{35}$ Op. cit., pp: $44-49$.
} 
caso particular de la metonimia: la de la parte por el todo. Pero nos interesa resaltar del trabajo de estos autores los tipos de metonimias que con mayor frecuencia aparecen en la lengua ordinaria como testimonio de su empleo, el cual responde y justifica el hecho de que el hablante proyecta en la lengua una determinada manera de ver y estructurar la realidad referencial, reflejo de la interdependencia entre lenguaje y concepción del mundo.

Tipos de metonimias:

a) El productor por el producto.- acabo de comprar un Ford, o tiene un Picasso en el despacho.

b) El objeto utilizado por la persona que lo utiliza.-El metro está en huelga, el primer violín está enfermo.

c) El responsable de una acción por la persona que la ejecuta.-Napoleón perdió en Waterloo.

d) La institución por las personas responsables.- El Senado considera el aborto una inmoralidad, no apruebo las acciones del gobierno.

e) El lugar por la institución.- La Casa Blanca no ha contestado, París ha presentado unas fladas más largas esta temporada.

f) El lugar por el acontecimiento.- Watergate ha cambiado la política americana.

Como en el caso de la metáfora la metonimia proyecta unas redes conceptuales que organizan el pensamiento y las acciones humanas. Con frecuencia se ha dicho que existe una diferencia estilística en el manejo de la metáfora y de la metonimia pues mientras la metáfora rompe la isotopía del discurso, la metonimia $\mathrm{no}^{36}$. $\mathrm{La}$ metonimia parece lexicalizarse con más facilidad que la metáfora. Sin embargo bajo los dos procedimientos tropológicos se da una construcción imaginativa. Lo que ocurre es que en la producción metonímica se relacionan términos concebidos como realidades referenciales más próximas, mientras que la producción metafórica permite conectar conceptos más alejados en nuestra representación referencial.

\subsection{Metonimia y semántica}

La metonimia es susceptible de ser definida como la sustitución de un término por otro en razón de la proximidad referencial del objeto o concepto denotado, aunque nosotros preferimos hablar de representación referencial. Los manuales y los estudios sobre este tropo acostumbran a enunciar, como hace por ejemplo Le Guern $^{37}$, las siguientes causas de producción metonímica: 1) La causa por el efecto;

${ }^{36}$ A este respecto señala Le Guern lo siguiente: «Utilizando la terminologîa de Greimas puede decirse que el lexema que forma metonimia o sinécdoque no es sentido como extraño a la isotopía, salvo en casos particulares muy raros. al contrario, la metáfora, a condición de que sea viviente y produzca imagen, aparece inmediatamente como extraña a la isotopía del texto en el que está inserta». Op. cit., pp: 18-19.

${ }^{37}$ Le Guern, op. cit., pp: 30-31; asimismo cf. M". V. García Arance: Semántica de la metonimia y de la sinécdoque, Valladolid, Universidad de Valladolid, 1979, pp; 73-75. 
2) el efecto por la causa; 3) el continente por el contenido; 4) el nombre de lugar o la cosa por la propia cosa; 5) el signo por la cosa significada; 6) el nombre abstracto por el concreto; 7) las partes del cuerpo consideradas como albergues de los sentimientos o de las pasiones, por esas pasiones y esos sentimientos, y 8) el apellido del dueño de la cosa por la propia cosa; el antecedente por el consecuente.

Como ya hemos repetido en varias ocasiones esta lista puede verse ampliada por la adición de otros dos nuevas causas, la de la parte por el todo y el todo por la parte, que constituyen los procedimientos de producción sinecdóquica.

En cuanto a la relación entre metonimia y referencia, también Le Guern parece sorprendido por el hecho de que la referencia, en tanto que realidad extra-lingüística se imponga y se manifieste en un cambio de sentido, (fenómeno lingüístico) y trata de conciliar esta contradicción en los siguientes términos ${ }^{38}$ :

La alteración de este sentido operada por la figura queda explicada por una alteración de la referencia entre dos objetos ligados por una relación extra-linguiística, puesta de manifiesto por una experiencia común que no está unida a la organización semántica de una lengua particular.

Pero si la alteración de referencia puede aparecer como un hecho exterior al funcionamiento del lenguaje, debemos reconocer que la intuición que nos obliga a considerar la metonimia y la sinécdoque como tropos nos impone, por el hecho mismo de ver aquí un cambio lingüístico, una modificación de la cadena hablada, con respecto a lo que hubiera tenido que ser normal.

La observación de Le Guern es acertada, ¿cómo es posible que algo ajeno al lenguaje puedaconfigurar la expresión lingüística? Sin embargo, tras esta apreciación sorprendente el autor no resuelve la pregunta implícita en su afirmación y se limita a constatar que la metonimia es un fenómeno lingüístico porque produce una modificación en la cadena hablada. Sin embargo no parece producir ningún tipo de sorpresa el hecho de que la similitud referencial entre objetos extra-lingüísticos modifique la cadena hablada en la producción metafórica; dicho más llanamente, ¿acaso no hay relación referencial y extra-lingüística en la metáfora rosa por mejilla en función del color rojo de ambas?, ¿la analogía no se basa en rasgos objetivos ajenos al lenguaje? Ya decía Aristóteles que metaforizar bien es percibir bien lo semejante.

Podemos pensar que en toda construcción tropológica la referencia tiene algo que decir, aunque no afirmamos con ello que sea el mundo, objeto exterior, el que determina la enunciación figurada, sino que es nuestro pensamiento el que al analizarlo y percibir series de unidades proyecta una imaginación constructiva capaz de jerarquizarlas en unas representaciones estructuradas. Estas representaciones son las que se reflejan en el lenguaje y como contrapartida una nueva proyección de la fantasía humana sobre estas representaciones (y no directamente sobre los objetos reales) autoriza, a través del lenguaje, el juego de nuevas construcciones cuyo reflejo son los tropos.

${ }^{38}$ Le Guern, op. cit., pp: 28-29. 
Al tratar Le Guern las motivaciones de la metonimia observa cómo en la comunicación normalmente las metonimias pasan desapercibidas y sólo mediante un análisis lingüístico son descubiertas. Pero a continuación pasa a ocuparse del momento de su producción y las causas de la misma. Considera este autor que el desplazamiento referencial es anterior a la enunciación figurada. Esta afirmación nos abre una nueva perspectiva: la alteración de la representación estructurada de la realidad se produce por una proyección imaginativa consciente, buscada o deseada o inconsciente e intuitiva, pero en tiempo anterior a la enunciación; es el momento de percibir bien lo semejante. Sin embargo, no podemos olvidar el proceso descodificador de la figura; en este proceso sí que el lenguaje es anterior a la reconstrucción imaginaria por parte del receptor del proceso inverso, esto es el receptor a partir del decurso figurado deberá proyectar su imaginación sobre la representación referencial y de este modo crear una estructura nueva semejante a la que dio origen al discurso tropológico.

No compartimos, sin embargo, las opiniones que fundan la metonimia en un error de percepción, en la pereza mental y discursiva. Esta consideración de la metonimia como un error viene determinada porque se plantea la relación troporealidad objetiva de forma inmediata y directa desde el prisma verdadero-falso, y como acabamos de exponer este no es el mecanismo productor de la figura. Tampoco creemos que se pueda calificar la producción metonímica de pereza mental o discursiva, ya que lo que se pone de manifiesto en el tropo es precisamente una actividad mental más intensa de la aque actúa en la enunciación lógico-referencial, pues hace intervenir un segundo proceso imaginativo.

Una descripción del proceso de creación metonímica desde una perspectiva semántica y lingüística nos la ofrece $\mathrm{A}$. Henry en los siguientes términos ${ }^{39}$ :

En métonymie, l'esprit, parcourant un champ sémique,, focalise sur un des sèmes et designe le concept-entité qui est l'objet de sa contemplation par le mot qui, en pur réalité linguistique, exprimerait ce sème, quand il est considéré en tant que conceptentité: ainsi, par exemple, un louis. L'esprit joue sur les rapports intersémiques, feint de ignorer l'ensamble des sèmes et se concentre sur l'un d'entre eux. Il faut donc bien distinguer le champ sémique --traduction conceptuelle et linguistique d'une certaine réalité, ou d'une cetaine «irréalité»——et la prise, plus ou moins libre et plus ou moins heureuse, qu'opère l'esprit.

En Henry la operación del espíritu parece acomodarse más o menos a lo que venimos denominando actividad de la imaginación, que se proyecta, no sobre una representación de la referencia, sino sobre el campo sémico del término propio, y, tras la selección de un sema busca el término que mejor exprese o ponga de relieve el sema elegido. Mediante la definición de lo que considera campo sémico, como traducción conceptual y lingüística, soslaya Henry el problema de la referencialidad.

Dada la visión de este autor sobre el proceso creador de la metonimia como actividad, operación del espíritu, no debe sorprendernos que rechace cualquier

${ }^{39}$ A. Henry, op. cit., pp: 25. 
hipótesis construida sobre la base de considerar el enunciado metonímico como pereza del pensamiento, y así lo manifiesta ${ }^{40}$.

Au lieu de paresse de pensée et d'insuffisance d'analyse, on pourrait parler tout aussi souvant d'interêt avivé, d'attention concentrée, de hiérarchie établie, et de désir de faire partager cet intérêt, d'autant que la situation ou le contexte verbal fournissent, ou doivent normalment fournir, fût-ce indirectement, tous le éléments indispensables de la structure logique.

No sabemos muy bien a lo que se refiere Henry cuando habla de jerarquía establecida, suponemos que esta jerarquía será la que se refleja en la organización de los semas, ni tampoco explicita lo que para él significa estructura lógica, ya que sólo hace referencia a la necesidad de que ésta se manifieste en el contexto situacional o verbal ${ }^{41}$.

\subsection{Metonimia y gramática.}

Los estudios morfosintácticos sobre la metonimia han despertado un menor grado de interés y desarrollo que los dedicados al proceso metafórico. El sentido metafórico puede surgir de la relación y combinación de los constituyentes discursivos, pero que el fenómeno metonímico pueda justificarse merced a las funciones de los lexemas y su status categorial no parece tan claro.

En el juego metonímico se ha atendido principalmente a la relación sustantivoadjetivo y a la función apositiva. A. Henry ${ }^{42}$, siguiendo a Nyrop, analiza una estructura metonímica como «tener el vino alegre», en la que el adjetivo se aplica a un sustantivo que es causa, mientras que el adjetivo alude a la consecuencia. Sin emabrgo, nos parece que en este caso el adjetivo, o más bien la relación entre el núcleo y el adyacente, no es la causa del proceso metonímico, sino que el adjetivo ejerce una función de marco (utilizando la terminología de M. Black) y facilita la descodificación de vino — causa - por borrachera - efecto-.

En cuanto a la metonimia en aposición Paz Gago la define ${ }^{43}$ :

Se trata de un tropo complejo cuyo funcionamiento consiste en relacionar 2 términos a través de un conjunto que engloba a ambos, conjunto del cual uno y otro son sinecdóticos. No hay interacción sino contigüidad por inclusión en el mismo conjunto.

${ }^{40}$ A. Henry, op. cit., pp: 29.

${ }^{41}$ Existe en la actualidad una creciente preocupación por las relaciones entre lógica, o más bien forma lógica y lingüística, sobre este punto vid. G. Fauconnier: «Y a-t-il un niveau linguistique de représentation logique?», Communications, 40, 1984, pp: 211-248.

${ }^{42}$ A. Henry, op. cit., pp: 21

${ }^{43}$ J. M². Paz Gago: «Tropos de sustantivos en aposición», Archivum, 31-32, 1981-82, pp: 666. 
La definición de Paz se inspira en el análisis retórico del Grupo $\mu$ y cita dos ejemplos de metonimia en aposición tomados de «Criaturas en la Aurora» de Vicente Aleixandre. El primero es un ejemplo de metonimia particularizante: «Ojo dulce, mirada repentina [...]» y el segundo lo es de metonimia generalizante «Era más bien la tersura, la mórbida superficie del mundo [...]». La relación metonímica entre los dos términos de la aposición es clara, aunque débil por la presencia en el mismo decurso de ambos. Se trata de metonimias in praesentia.

\section{SINÉCDOQUE}

La sinécdoque ha sido definida como el tropo de la parte por el todo y del todo por la parte. Ya hemos comentado en páginas anteriores cómo su independencia tropológica no es unánimemente aceptada, no insistiremos más en ello.

Junto a la sinécdoque de la parte y la del todo, como señala Le Guern, la Retórica llegó a especificar seis tipos más de sinécdoque:

Sinécdoque de la materia en la que se puede apreciar un procedimiento metonímico.

Sinécdoque de la especie; enunciar la especie en lugar del género es un procedimiento en el que, según Le Guern, deben distinguirse dos posibilidades: una, si la especie no presenta incompatibilidad en el mensaje y hay coincidencia referencial, en tal caso no es lícito hablar de tropo. Otra posibilidad es la de que efectivamente se esté sustituyendo la especie por el género, como en el caso de «noche zulú», donde es necesario poner en suspenso los semas incompatibles con el contex to y en consecuencia estaremos ante un proceso metafórico y no sinecdóquico.

Sinécdoque del género: consiste en la enunciación del género por la especie. Le Guern le niega el calificativo de verdadero tropo en razón de que el desplazamiento se produce a través de la relación referencial, y considera que es más apropiado hablar aquí de denominación por caracterización. No se equivoca el autor al negarle el carácter tropológico a esta supuesta sinécdoque, pero no lo es por el hecho de que el emisor elija una relación referencial, sino porque en su producción no se da una segunda proyección imaginativa sobre la representación mental de la referencia; cuando decimos pez por trucha o árbol por encina la sustitución de términos no produce una nueva representación mental ni una nueva relación distinta entre el enunciado y la estructuración que hemos asignado a los objetos en nuestra concepción del mundo. La falta de precisión en la denominación es un hecho cotidiano en el lenguaje llamado referencial; podemos enunciar oraciones sin sujeto sobre la base del mismo fenómeno por desinterés, o por desconocimiento de quien realiza la acción.

Sinécdoque de abstracción, consiste en tomar lo abstracto por lo concreto, proceso en el que se puede apreciar una relación metonímica.

Sinécdoque del individuo o antonomasia. Dentro de este tipo de sinécdoque cabe distinguir dos variantes; a saber: la primera, en la que se sustituye el nombre propio de una persona por un término genérico, en cuyo caso estamos ante una abstracción y no ante un tropo; la segunda es inversa, la enunciación de un nombre propio por 
un nombre común, pero en este caso la razón del tropo ya no es la contigüidad, sino la semejanza, por tanto se trata de un tipo de metáfora.

La sinécdoque queda por consiguiente reducida, por las razones antes analizadas, a dos subclases, la de la parte por el todo y el todo por la parte. Esta figura lo que realiza es pues una reorganización de las relaciones y la estructura de los objetos, efecto de la proyección imaginativa macroscópica o microscópica sobre la representación mental del mismo.

\subsection{Sinécdoque y lenguaje referencial}

Al igual que los dos tropos estudiados, la sinécdoque no es sólo un recurso artístico y una convención; también este tropo aparece y conforma la lengua coloquial. Así lo demuestran Lakoff y Johnson, aunque lo consideran una subclase de metonimia, como ya dijimos anteriormente, en el trabajo que venimos comentando de estos autores. Frases como «no me gustan las melenas» 0 «me he comprado un 9caballos» tienen un uso extendido en nuestra sociedad y no insistiremos más en é ${ }^{44}$.

\subsection{Sinécdoque y semántica}

A partir de los conceptos extensión y comprensión establece A. Henry la diferenciación entre sinécdoque y metonimia ${ }^{45}$ :

La synecdoque opère un changement dans l'extension logique du mot; elle substitue à un mot un terme d'extension différente. La métonymie opérait un changement dans la compréhension logique d'un mot; elle sustitue à un terme de compréhension différente.

Esta es la consecuencia semántica de la utilización de estos tropos, pero el mecanismo productor de la sinécdoque es en palabras de Henry el siguiente ${ }^{46}$ :

En synecdoque, l'esprit joue, pour réaliser les modifications d'extension psycologique, sur des rapports sémiques entre éléments d'un même champ associatif; il superpose les champs sémiques de deux termes contigus, c'est-à-dire appartenant à un même champ associatif, ne retient qu'un ou des des caractéres communs, et opère la substitution de termes.

Considera este autor que sinécdoque y metonimia son consecuencia de un mismo fenómeno, el desplazamiento por contigüidad. Sin embargo, el proceso de creación y las consecuencias semánticas son diferentes en uno y otro tropo; modificación de la comprensión y de la extensión lógica y actuación del espíritu ya en un campo

\footnotetext{
${ }^{44}$ Vid. G. Lakoff y M. Hohnson, op. cit. pp: 46.

${ }^{45}$ A. Henry, op. cit., pp: 19.

${ }^{46}$ Ibid., pp: 25.
} 
sémico ya en un campo asociativo marcan la diferencia. Este tratamiento no unitario metodológicamente es criticado por García Arance ${ }^{47}$, quien considera necesario un tratamiento de ambos tropos desde un mismo punto de vista, y ello es demostrable, según esta autora, atendiendo al plano del contenido y al de la expresión, pues la sinécdoque consiste en la extensión del significado del signo poético con respecto al signo lingüístico base —el significante está incluido en el significado-; mientras que la metonimia se caracteriza por la restricción del significado del signo poético con respecto al signo lingüístico base, en consecuencia el significante incluye al significado.

Para los autores del grupo $\mu^{48}$ existen dos clases de sinécdoques: la generalizante y la particularizante; en ambas se da una supresión de parte de los semas del término. Sin embargo, si se suprimen semas esenciales (indispensables para la comprensión del discurso) el mensaje se vuelve ininteligible.

\section{LOS TROPOS Y LA ESTRUCTURA SEMÁNTICA DEL UNIVERSO}

Hemos insistido, en repetidas ocasiones, sobre la necesidad de una visión organizada del mundo que permita explicar por qué se producen estos desplazamientos tropológicos, estos pequeños escándalos léxicos, como se les ha llamado en alguna ocasión. Sin una visión del mundo estructurada los tropos serían enunciados indescifrables, se bloquearía toda posibilidad de descodificación del discurso sin sentido. Y ya hemos visto como los tropos producen, por el contrario, un significado nuevo, son creadores de una red conceptual nueva que organiza nuestro pensamiento.

La necesidad que el ser humano siente de estructurar el mundo es un fenómeno cultural que ha sido ampliamente reflejado a lo largo y ancho de la historia del pensamiento; así, por ejemplo, Aristóteles buscaba una justificación de la pluralidad real partiendo de la sustancia y la combinación de los accidentes, en un movimiento del uno hacia lo diverso; la representación organizada y jerarquizada de la realidad en forma arbórea podemos encontrarla en Porfirio y en R. Lulio ${ }^{49}$ (la imagen del árbol es metafórica) e incluso las tendencias semánticas más actuales de la Gramática de Casos reflejan una visión estructurada de las relaciones que se producen en los acontecimientos ${ }^{50}$. Pero frente a esta situación cabe hacernos algunas preguntas: $\iota^{\text {es }}$

${ }^{47}$ Vid. M‥ R. García Arance, op. cit., pp: 43.

${ }^{48}$ Cf. Dubois, VV.AA., op. cit., pp: 105.

${ }^{49} \mathrm{El}$ árbol de Porfirio ha sido utilizado por U. Eco para explicar el desplazamiento y sustitución de términos en la metáfora. Vid. U. Eco: «Metaphor», Semiotics and philosophy of language, Bloomington, Indiana University Press, 1984. Sobre el árbol de Raimundo Lulio cf. R. Llull: Obra escogida, Madrid, Alfaguara, 1981, pp: 519 y ss.

${ }_{50}$ Para el estudio de la gramática de casos vid. W. L. Chafe: Meaning and the structure of language, Chicago, University Press, 1976 (tr. cast. J. A. Domínguez Martínez: Significado y estructura de la lengua, Barcelona, Ensayos Planeta, 1976; Ch. J. Fillmore: «Some problems for case grammar». Publicado en O'Brien (ed.): Annual Round Table on Linguistics and Language Studies (tr. cast. V. Sánchez de Zavala: «Algunos problemas de la gramática de casos», en Semántica y sintaxis en la lingüística transformatoria, Madrid, Alianza Editorial, 1976. Ch. J. Fillmore: «Hacia una teoría moderna de los casos» (tr. cast. de H. Contreras en Los fundamentos de la gramática transformacional, Méjico, Siglo XXI, 1974), Ch. Gutkenecht y K. Panther: Lingüística generativa, Madrid, Oriens, 1978. 
universal esta representación del mundo?, y su reflejo en el léxico ¿es igualmente universal? Si la creación de los tropos supone una alteración de esta visión organizada del mundo ¿son constantes y universales estas alteraciones?

Creemos que la necesidad de una visión organizada de la realidad es un fenómeno humano universal y, básicamente, estas estructuras son semejantes en cada una de las comunidades culturales, aunque no necesariamente iguales en cada grupo étnico ni en cada época. Estos esquemas son por tanto modificados según la realidad y la cultura del momento. Sin embargo, las diferencias no son tan notables como para impedir su comprensión o para no poder establecer comparaciones; pensemos por ejemplo en el caso de un nuevo descubrimiento; el conocimiento de una nueva realidad debe tener su reflejo en una nueva organización mental del mundo, o por el contrario el desconocimiento de un objeto en una cultura dada hace incomprensible el término que lo designa. Tal fue el caso de los misioneros quienes al cristianizar al pueblo esquimal se vieron obligados a cambiar la expresión «cordero de Dios» por «foca de Dios» ya que el término cordero no significaba para ellos ningún objeto conocido.

Estas diferencias no autorizan, sin embargo, a negar el hecho de que el hombre ordene, estructure y jerarquice su entorno y ello gracias al lenguaje, así lo expresa K. Baldinger ${ }^{51}$ :

La lengua divide el mundo y hace de la infinita multiplicidad de la realidad un cañamazo abarcable y divisible. La lengua ordena y articula la infinitud de lo concreto, pero también la realidad espiritual. Nosotros vemos el mundo a través de este cañamazo formado por el lenguaje. Esto no es otra cosa que el «entremundo» conceptual, la imagen idiomática del mundo de que ya habló Wilhelm von Humboldt.

Sin embargo expresa Baldinger serias reservas sobre la posibilidad de construir un sistema jerarquizado de conceptos; observa cómo en el intento llevado a cabo por Hallig y Wartburg se pueden apreciar notorias deficiencias y cree que nunca se podrá llegar a una representación conceptual objetiva y universal por el carácter multilateral de las relaciones conceptuales, por las variaciones que el tiempo introduce, de modo que sólo es posible obtener sistemas conceptuales parciales independientes de la lengua y del tiempo.

La dificultad señalada por Baldinger es obvia, ya que es fruto precisamente de la interrelación mundo-lenguaje. El lenguaje permite configurar el mundo, pero cada término del léxico presenta una recursividad que conduce, como ha señalado $\mathrm{Eco}^{52}$, hacia una semiosis ilimitada. Cada lexía lleva en su significación una serie de lexías implicadas que remiten nuevamente a sucesivas implicaciones. Esto es un inconveniente cuando se quiere dar mediante el léxico una visión simple y objetiva de la realidad. Además los términos pueden ver aumentadas sus explanaciones o modificadas por el transcurso de los acontecimientos y del tiempo si contemplamos cada uno de los términos a modo de enciclopedia y no como entradas de un

${ }^{51}$ K. Baldinger: Teoría semántica. (Hacia una semántica moderna), Madrid, Alcalá, 1977, pp: 105.

${ }^{52}$ U. Eco: Lector in fabula, Barcelona, Ed. Lumen, 1981. 
diccionario. Estas dos objeciones son sin embargo las que permiten dar una completa justificación del fenómeno tropológico.

Lo que es un hecho innegable es que el hombre contempla la realidad a través de unas coordenadas imaginarias que dividen los objetos, e incluso las concepciones más abstractas, en porciones a las que les asigna un rótulo. El lenguaje puede de este modo reflejar la estructura proyectada por la imaginación y así comunicar su estructura y la jerárquica relación entre las partes al resto de la comunidad de hablantes. Cuando contemplamos un edificio, observamos que consta de diferentes partes: tejado, fachada, etc.; si observamos un ser vivo lo descomponemos en cabeza, tronco y extremidades. La propia superficie terrestre está recorrida por líneas imaginarias, los polos, paralelos y meridianos. Toda persona tiene consciencia de su primera división entre el yo y el no yo y en el no yo establece la división entre lo animado y lo inanimado así va determinando sucesivas subdivisiones hasta obtener una representación del entorno en el que se mueve, división que comunica mediante el lenguaje y que hace perceptible al resto de la comunidad. El lenguaje es por tanto instrumento de clasificación y vehículo de comunicación de dicha clasificación.

El lenguaje, en consecuencia, permite que la imaginación del receptor construya un esquema idéntico de la realidad al organizado por el emisor y de este modo surge la comunicación entre ambos. Pero la dificultad aparece cuando se observa que el hombre es capaz de construir diferentes esquemas mentales de la realidad, y esto es lo que apreciaba Baldinger; es imposible considerar un esquema único, total y universal de la representación conceptual del universo, sólo obtenemos estructuras parciales. Esto es debido a que la imaginación puede construir diferentes modelos de estructuras, sobre todo cuando se proyecta sobre realidades abstractas, menos objetivas, menos referenciales. Pensemos por ejemplo en el caso de los gramáticos cuando tratan de analizar un decurso, clasificarlo por sus funciones y significados. El resultado no es en modo alguno uniforme, para unos la primera división será entre lo que se afirma y sobre quién se afirma estableciéndose una división entre sujeto / predicado o tópico / comentario. Otra posibilidad es la de contemplar el discurso como portador de información sustancial y accesoria: actantes / circunstante. Se puede analizar por el comportamiento diferente de las distintas unidades que componen el enunciado: sujeto, complemento directo o implemento, etc., o bien es posible establecer un análisis por los contenidos semánticos: agente, objeto, beneficiario, instrumento, etc. Estos diferentes métodos de analizar reflejan intereses diferentes que no son en absoluto erróneos, sino que responden a las variadas formas de representación y análisis del objeto, gracias a su enunciación linguística podemos reconstruirlos y representarlos en nuestra imaginación.

\subsection{Alteraciones tropológicas}

Si bien es cierto, como acabamos de observar, el hecho de que el hombre puede construir diferentes esquemas estrucuturados de la realidad, ello no implica una representación diferente para cada individuo, pues existen representaciones 
convencionalizadas que han pasado a constituir parte del acervo cultural de la comunidad humana o bien de comunidades particulares. Ciertas representaciones mentales de la realidad quedan así fijadas como patrimonio cultural.

Cuando enunciamos un tropo lo que el receptor recibe es una alteración de estas representaciones mentales, una inadecuación entre la ordenación establecida por la comunidad y la que el discurso refleja. Esto obliga al receptor a proyectar una nueva actividad imaginativa para recorrer el proceso de formación tropológica hasta descubrir el nuevo orden atribuido por el emisor.

Sabemos que los seres y los objetos están convencionalmente divididos en partes, por ejemplo la casa tiene una parte llamada techo, la cabeza es una de las partes de una res, pues cuando enunciamos decursos como:

- Este hombre no tiene un techo

- He comprado un rebaño de cien cabezas

hacemos que un rótulo que ocupa en nuestra representación mental del objeto un nudo inferior ascienda al nudo superior.

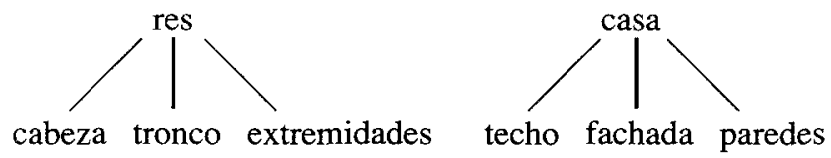

La sinécdoque opera un cambio en la estructura del objeto ascendiendo o descendiendo un nudo en su representación.

Una pregunta que puede surgirnos es por qué cuando utilizamos estas sinécdoques determinadas partes del objeto se convierten en representativas de la totalidad y no ocurre lo mismo con otras partes, ¿por qué no decimos que hemos comprado un rebaño de cien patas, este hombre no tiene una pared, o que hemos visto en el mar treinta timones en lugar de treinta velas? Estas sustituciones están convencionalizadas en nuestra cultura y responden a la caracterización visual del objeto en unos casos, como en el ejemplo de la vela por el barco o la cabeza por la res; son las partes distintivas y sobresalientes, son partes caracterizadoras: la cabeza o el rostro de los seres permiten la identificación del individuo, cuando solicitamos nuestra documentación, pasaporte o D.N.I. junto a las huellas dactilares, verdadero rasgo individualizador, debemos adjuntar una fotografía de nuestro rostro, no de la totalidad de nuestro cuerpo, pues el rostro nos caracteriza, individualiza y define visualmente. En otros casos la parte representativa del todo se elige en función de su finalidad, si decimos techo por casa es porque en nuestra representación del objeto la finalidad de la techumbre es la de proporcionar protección y cobijo.

Junto a esta clasificación de los objetos que podríamos llamar microscópica y estática nuestra imaginación es capaz de estructurar y concebir el léxico como resultado de una actividad implicada en el término, por ejemplo un cuadro es el producto de la actividad de un pintor, un instrumento musical lleva implicado un agente que lo ejecute, un lugar puede ser contemplado como la fuente, el origen de 
un producto, o el origen de un acontecimiento, etc.. Esta perspectiva dinámica del léxico permite un nuevo tipo de desplazamientos tropológicos, el de la metonimia. El componente dinámico en las implicaciones significativas de los términos permite por tanto diferenciar la sinécdoque de la metonimia; en ésta, el desplazamiento es igualmente en dirección ascendente o descendente de un nudo, pero la estructura originaria que establece la representación mental encierra una dinamicidad que la sinécdoque desconoce. Cuando decimos que el primer violín está enfermo, nos representamos una situación en términos de actividad, un agente, una acción y un instrumento; el desplazamiento se produce por la sustitución del agente por el instrumento. Lo que tienen en común la sinécdoque y la metonimia es que ambos desplazamientos se producen dentro de las ramas de un mismo nudo, en el seno del objeto, para la sinécdoque, en el seno de las relaciones actanciales y circunstanciales para la metonimia.

La metáfora exige un procedimiento más complejo, por ello es la reina de los tropos, el mayor escándalo léxico. Frente a la proximidad o contigüidad de la sinécdoque y la metonimia, la metáfora precisa una representación mental de la realidad más amplia; en cualquier caso, para que se produzca la metáfora debe existir un doble desplazamiento ascendente y descendente desde el término tenor hasta el vehículo, ambos están dominados por un nudo común. U. Eco lo expresa haciendo referencia al árbol de Porfirio. Según este autor, cuanto más alto sea el nudo que domina a ambos términos mejor será la metáfora. Cuando decimos que una muchacha es un junco el nudo común sería orgánico; este nudo que estará dividido en animal -vegetal permite el desplazamiento del término muchacha inserto en el nuevo nudo animal hasta el de junco, inserto en el nudo dominado por el carácter vegetal. De este modo quedan en suspenso las características propias de lo vegetal y se refuerzan los semas comunes de flexibilidad, gracia, fragilidad que nuestra cultura atribuye tanto a la muchacha como al junco. Por este doble desplazamiento que la metáfora exige para su enunciación no es extraño que este tropo haya sido definido como doble sinécdoque o doble metonimia pues lo que se apreciaba era precisamente la necesidad de un doble salto que permita pasar de una rama dominada por un nudo a otra rama dominada por un nudo diferente.

Cuanto llevamos dicho hasta el momento pone de manifiesto que la creación tropológica exige previamente una doble actividad imaginativa, de una parte la que produce una representación organizada del mundo y de otra la reorganización de esta estructura que da como resultado la creación de los tropos.

Si Aristóteles aconsejaba que para metaforizar bien es preciso percibir bien lo semejante, y no debemos olvidar que para el estagirita metáfora era el término que incluía a todos los tropos, lo que estaba aconsejando era la percepción clara de la representación mental del mundo y el conocimiento de los mecanismos que permiten su reestructuración.

\section{LOS TROPOS Y LA GRAMÁTICA}

Ciertos sectores de la lingüística han venido considerando que el estudio de los tropos era una materia reservada al ámbito literario y en consecuencia la gramática 
no estaba obligada a dar cuenta de la producción y descodificación de lo que para ellos no era otra cosa que un desvío en el uso del lenguaje ${ }^{53}$. Esta opinión era el resultado de unas ambiciones cientificistas, del desprecio por los aspectos significativos del discurso y en otros casos debido a un pensamiento débil que, incapaz de encontrar solución satisfactoria al problema tropológico, optaba por st: desentendimiento. Afortunadamente esta situación esta siendo superada en los últimos tiempos ya que el uso de los tropos no puede ser circunscrito al estrecho ámbito de lo literario (hemos visto en páginas anteriores cómo los tropos son capaces de aparecer en cualquier tipo de enunciados) y no es justo apartar su uso del lenguaje estándar, aséptico, porque ningún uso del lenguaje es totalmente inocente ${ }^{54}$. En la actualidad sólo los sectores más recalcitrantes persisten en estas creencias y continúan considerando los tropos como desvíos del lenguaje sin interés para el lingüista.

Un modelo de gramática debe poder dar cuenta de todos los usos que los hablantes hacen de su lengua. Intentaremos por tanto dar cuenta de la creación de los tropos en el marco metodológico de la gramática generativa ya que este modelo trata de reflejar el conocimiento interiorizado que los hablantes tienen sobre el contenido de los decursos y que los habilita para hacer un uso creador de su lengua.

A partir de 1980 se ha venido desarrollando dentro de la gramática generativa un modelo denominado «Rección y Ligamiento» ${ }^{55}$, que ofrece las ventajas de: 1) presentar una simplificación en la aplicación de las reglas de transformación, 2) una mayor atención a los sistemas de principios. Según este modelo en la generación oracional caben distinguir cuatro tipos de representaciones: estructura profunda, estructura superficial, forma fonética y forma lógica. Junto a estos cuatro niveles de representación actúan una serie de principios o módulos que aseguran la buena formación de las oraciones generadas. En cuanto a las reglas de transformación, de la estructura $\mathrm{P}$ a la estructura $\mathrm{S}$, sólo existe una regla: muévase $\alpha$ donde $\alpha$ equivale a una categoría. Un esquema simple que pueda dar cuenta de este modelo sería:

${ }^{53}$ Lyons a propósito del divorcio entre lingüística y teoría literaria comenta: «Lamentablemente, cn los últimos años parece que se ha abierto un vacío entre la lingüística y los estudios literarios. En buena medida se debe a la incomprensión y los prejuicios, por una parte, y a las pretensiones exageradas que han introducido determinados lingüistas y críticos literarios acerca de los objetivos y logros de sus respectivas disciplinas. $Y$ aunque la incomprensión y los prejuicios aún perduran en determinados bastiones de ambos lados, también es verdad que van reduciéndose paulatinamente». Vid. J. Lyons: Introducción al lenguaje y a la lingüística, Barcelona, Teide, 1984, pp: 256.

54 Todorov afirma que: «Todo es natural o todo es artificial, pero no existe un grado cero de la escritura, no hay una escritura inocente, el lenguaje más neutro está tan cargado de sentido como una expresión extravagante». Vid. T. Todorov: Literatura y significación, Barcelona, Planeta, 1974, pp: 212.

55 Sobre el modelo de Rección y Ligamiento pueden consultarse entre otros los siguientes trabajos: N. Chomsky: Lectures on Government and Binding, Dordrecht, Foris Publications, 1984; N. Chomsky: La mueva sintaxis. Teoría de la rección y el ligamiento, Barcelona, Paidós Comunicación, 1988; H. van Riemsdijk y E. Williams: Introduction to the theory of grammar, Cambridge, Massachuselts, The MIT Press, 1986; V. Demonte y M. Fernández Lagunilla: Sintaxis de las lenguas románicas, Madrid, El Arquero, 1987; V. Demonte: «Principios y representaciones en sintaxis: la teoría de la rección y el ligamiento», Verba, 10, 1983, pp: 5-42. 

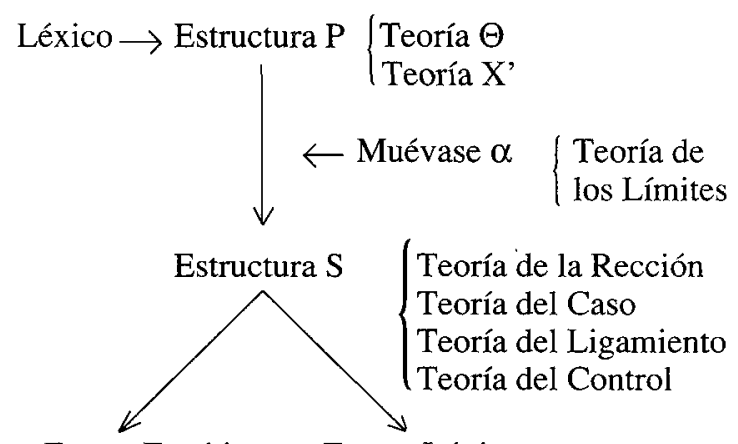

Forma Fonética Forma Lógica

En la Estructura Profunda se insertan las unidades léxicas que reúnen no sólo la información significativa de los términos, sino que éstos están además marcados por rasgos de subcategorización que nos indicaran si un $\mathrm{SN}$ es portador del rasgo [+animado], [-humano], [+concreto], etc. Igualmente marcará los verbos, según su significado, por la posibilidad o imposibilidad de combinarse con SSNN y los rasgos de subcategorización que deben tener estos SSNN. De este modo, se asegura, desde la EP, la buena formación de los enunciados, impidiendo ciertos tipos de agramaticalidad e inaceptabilidad. Además, la EP está sometida a las teorías de $\Theta$ y X'.

La teoría $\Theta$, o teoría de los papeles temáticos, es la que asigna un papel temático de «agente», «paciente», «meta», «instrumento», etc. a los argumentos; esta asignación se hace teniendo en cuenta el significado del núcleo que asigna el papel temático; es decir, los verbos o los núcleos de los sintagmas léxicos, y pueden ser agumentos las expresiones referenciales, como son los SSNN y las cláusulas. Los argumentos reciben sólo un papel temático, y los papeles temáticos no se pueden asignar más que a los argumentos, sean externos, como los sujetos, o internos, como los complementos.

La teoría de la X' recoge las semejanzas que existen entre las cuatro categorías sintácticas que poseen un núcleo de un sintagma; esto es, pueden expandirse mediante complementos y especificadores, por tanto $\mathrm{X}=\mathrm{SV}, \mathrm{SN}, \mathrm{SA}, \mathrm{SP}$.

La teoría de los Límites impide que el desplazamiento de una categoría a se haga de forma arbitraria, por lo que incluye el principio $\Theta$ por el que el desplazamiento no puede hacerse a posiciones en las que deba asignarse un nuevo papel temático; es decir, el desplazamiento de $\alpha$ debe hacerse a una posición no-temática. Asímismo, el Principio de subyacencia impide que al desplazarse a ésta atraviese más de un nudo cíclico o nudo límite; son nudos cíclicos los SSNN, O y O' en las lenguas románicas. El desplazamiento de a deja en su posición primera una huella.

La teoría de la Rección es la que determina la relación entre un núcleo y los elementos que dependen de dicho núcleo. Dentro de esta teoría opera el Principio de la Categoría Vacía. Según este principio, deben estar regidas también las huellas que deja la aplicación de la regla de desplazamiento de $\alpha$, e igualmente deben estar regidas las categorías que carecen de contenido fonético o categoría vacía. 
La teoría del Caso es la encargada de asignar la marca de caso a aquellos elementos que puedan recibirlo dada su posición; por ejemplo, el complemento directo de un verbo transitivo, los sujetos de los verbos flexivos, etc. Todos los SSNN que posean un contenido fonético deben recibir una marca de caso. La marca de caso exigirá en determinadas lenguas una variación morfológica. Está claro que existe una interrelación entre la asignación del caso y la asignación de papeles temáticos. Asignadores de caso son, en la estructura $S$, el verbo y la flexión, pero en la estructura $\mathrm{P}$ asignan también caso: el nombre, el adjetivo y la preposición.

Con la Teoría del Ligamiento quedan reguladas las relaciones referenciales de los argumentos que componen la oración, ya sea una referencialidad extra o intradiscursiva. Estos constituyentes sintácticos pueden ser de tres clases: expresiones referenciales, anáforas y pronombres. Esta teoría establece las condiciones en que estos argumentos están o no ligados, es decir, si el antecedente manda o no caso.

Por último, la Teoría del Control tiene como misión fundamental controlar las relaciones entre un pronombre y su antecedente, si lo hay. Los pronombres presentan una situación intermedia entre las expresiones referenciales y las anáforas; su distribución precisa el concurso de otros principios como el de Rección, Ligamiento, Teoría del Caso y Principio de Subyacencia.

Este resumen, quizás rápido y tosco, (no es este el momento, ni el lugar adecuado para profundizar en cuestiones de gran complejidad que este modelo gramatical, sin duda, suscita) tiene la finalidad de dar una somera descripción sobre el funcionamiento de este aparato metodológico. Es cierto que la atención de ciertos lingüistas que trabajan con este potente mecanismo capaz de describir el proceso creador del lenguaje se ha obstinado en trabajar con decursos en los que se prescinde de los llamados usos anómalos o desviados del lenguaje; no es menos cierto que el modelo sirve de base para la justificación de los mismos.

Antes de dar cuenta del mecanismo capaz de crear los tropos en el seno de esta metodología, debemos hacer referencia a una cuestión previa. La gramática generativa ha trabajado con cuatro conceptos que ahora nos interesa destacar: competencia, actuación, gramaticalidad y aceptabilidad ${ }^{56}$. Por competencia se entiende el conocimiento interiorizado que el hablante posee de la gramática; la actuación es la manifestación de la competencia que se refleja en los enunciados. La gramaticalidad es la condición de las oraciones bien formadas, es decir, adecuadas a la gramática, y la aceptabilidad exige que los decursos sean, además de gramaticales, dotados de un sentido lógico; así, un enunciado como: niño el comió pastel un se es agramatical, mientras que un pastel se comió al niño es considerado inaceptable. El concepto de gramaticalidad se ha relacionado con el de competencia lingüística y el de aceptabilidad con el de actuación.

Según los criterios que acabamos de enunciar, la creación tropológica sería considerada, y así se ha manifestado en algunas ocasiones, como un caso de construcción inaceptable o desviada, en consecuencia, relacionada con la actuación lingüística. Sin embargo, si los tropos surgen de la reorganización de la representación

${ }^{56}$ Sobre el problema de competencia y actuación en la producción metafórica vid. R. Horrocks: «Metaphor in competence and performance», Papers in linguistics, 1976, 1-2, pp: 147-171. 
mental de la realidad que afecta al léxico, debe ser contemplada como un patrimonio de la competencia lingüística de los hablantes. La producción đe los tropos se realiza en el momento de la selección léxica en la estructura $P$.

La Gramática Generativa, tal y como hemos visto en el esquema, sitúa al lexicón en la estructura P. Allí se organizan las entradas léxicas gracias a un mecanismo fronterizo entre la sintaxis y la semántica. La subcategorización ${ }^{57}$ de las piezas léxicas determina la distribución sintáctica de los lexemas y la selección, su distribución semántica; de este modo se impide la generación, ya en la estructura $P$, de oraciones agramaticales e inaceptables. Pero no es menos cierto que también impediría la formación de decursos portadores de sentidos figurados; en consecuencia, los tropos no podrían existir, o al menos, no pueden encontrar una justificación plausible. Por ello debemos revisar el concepto de lexicón.

El lexicón, tal y como parece ser concebido por la GG, es una especie de información léxica que el hablante posee, a modo de diccionario, en el que junto al significado de las palabras se añade una infirmación sobre sus rasgos de subcategorización, basados en el significado del término. Este concepto debe ser modificado, pues el hablante, junto a cada término, posee una información no sólo del significado, sino también de los diferentes sentidos que el término suscita en el seno de la comunidad cultural a la que pertenece; es decir, su conocimiento del léxico no es a modo de diccionario; es a modo de enciclopedia. Ya Eco ha señalado, en repetidas ocasiones, esta necesidad de una visión enciclopédica del léxico que permita dar cuenta del entretejido sémico que se crea en torno a cada $v_{0 z}{ }^{58}$ :

El modelo regulativo de una enciclopedia prevé, en cambio, varios «sentidos», o sea diversas disyunciones posibles de un aspecto semántico idealmente completo.

La concepción del léxico como enciclopedia presenta una desventaja: su recursividad en la explanación sémica, pues cada uno de los semas que componen un término puede ser nuevamente explanado con nuevos términos lingüísticos. Esta regresión hacia el infinito posee, según Eco, un límite lógico que detiene esta semiosis ilimitada: el universo discursivo.

Junto a la información enciclopédica el lexicón ha de estar estructurado, ya que es el reflejo de la representación mental de la realidad que poseen los hablantes de una comunidad. Esta estructura jerarquizada, común a todos los hablantes, es el resultado del trabajo constructivo de la imaginación colectiva.

El lexicón, configurado de este modo, aparece dotado de una información más rica y más fiel del conocimiento que tienen los hablantes de una cultura dada, pero no nos explica todavía nada sobre la posibilidad de producir enunciados figurados. El hablante posee además en su información léxica un rasgo que podemos denominar [+retórico] y que nos indique el uso particular que hace de la representación mental de la realidad alterando dicha estructura; cuando proyecta su imaginación sobre esta 181-209.

Cf. R. Carter: «Sous-catégorisation et régularités sélectionnelles», Communications, 40, 1984, pp:

${ }^{58}$ U. Eco: Lector in fabula, Barcelona, Lumen, 1981, pp: 56. 
estructura y crea una nueva reorganización activa el rasgo [+retórico] y de este modo coindiza los términos sustituidos, los sustituyentes y el nudo que domina a ambos.

Un esquema simple de esta propuesta es el que reflejan las siguientes figuras:

Fig. 1

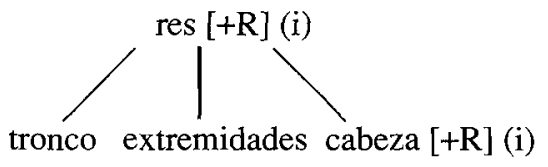

Fig. 2

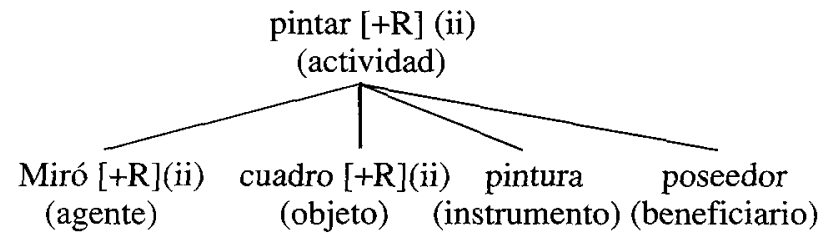

Fig. 3



La coindización permite que el enunciado metafórico sea descodificado correctamente a partir de la inadecuación observable en el decurso entre el marco y el foco (según la terminología de Black) ${ }^{59}$.

Somos conscientes de que la solución que acabamos de esbozar requerirá sin duda un estudio más atento y minucioso, sin embargo estamos convencidos de que puede abrir unas nuevas perspectivas en el estudio gramatical de los tropos.

${ }^{59}$ Leech utiliza estos conceptos no sólo para la captación metafórica, sino que marcan la diferencia con el símil: «...the capability of metaphor (as opposed to simile) to suggest a connexion between the explicit vehicle (represented by the deviant item) and a less tangible cluster of associations constituiting the tenor», vid. G. N. Leech: «Linguistics and the Figures of Rhetoric», Essays on style and language, London, Routledge and Kegan Paul, 1979, pp: 135-156. 


\section{LOS TROPOS, RECURSO LITERARIO Y POÉTICO}

Hemos repetido hasta la saciedad que el hecho irrefutable de que las construcciones tropológicas no pueden ser limitadas a un único ámbito discursivo. Los tropos constituyen un artificio, una convención lingüística que, fruto de la actividad imaginaria, hace surgir un conocimiento nuevo de la realidad, una organización nueva del mundo y en ello radica su valor expresivo, su escándalo y su sorpresa. Por todo esto es fácil comprender que estos artificios lingüísticos hayan sido usados con fines retóricos y poéticos.

Pero hemos de distinguir cuidadosamente entre la intencionalidad de su uso y su efecto estético, pues el simple uso de los tropos como artificio y la voluntad literaria del autor no implica un seguro resultado artístic ${ }^{60}$. A este respecto García Berrio ha establecido una acertada distinción entre literaridad y poeticidad ${ }^{61}$ :

Lo que la poesía es, lo es en virtud del valor de poeticidad, que como propiedad estética característica reconocemos en determinados, y no en todos o en cualquiera, discursos literarios.

Concibo la literaridad como la propiedad específica de los textos verbales convencionalizados como literatura, en términos de decisión cultural, una opción o iniciativa restringida, puesta en acto en el momento de construir bajo un modelo singular de «norma» un determinado tipo de texto verbal con intencionalidad artística.

Los tropos son indudablemente recursos expresivos que el autor puede utilizar con intención de construir un discurso literario, además exige el concurso de la imaginación, que como señala Hegel ${ }^{62}$ es la que capta y engendar representaciones y formas con las que da una expresión figurada, sensible y precisa a los intereses humanos más profundos y más generales. Por estas razones pueden ser considerados como marcas o indicios de una construcción poética, pese a que el valor es siempre un hecho imprevisible y no convencionalizable.

${ }^{60}$ La necesidad de distinguir entre los conceptos de poeticidad y literaridad aparece enunciada en la obra de D. Delas y J. Filliolet: Linguistique et poétique, Paris, Larousse, 1973, pp: 43-45. Sin embargo el desarrollo y la clarificación de estos conceptos lo ha realizado A. García Berrio: «Lingüística, literaridad/poeticidad. (Gramática, Pragmática, Texto)», 1616. Anuario de la Sociedad Española de Literatura General y Comparada, 2, 1979, pp: 125-170.

${ }^{61}$ A. García Berrio: «¿Qué es lo que la poesía es?»,Lingüística Española Actual, IX-2, 1987,pp: 180.

${ }^{62}$ G. W. F. Hegel: Introducción a la estética, Barcelona, Ediciones Península, 1979, pp: 80. 